\title{
Cardiovascular protection of magnolol: cell-type specificity and dose-related effects
}

\author{
Jennifer Hui-Chun $\mathrm{Ho}^{1,2,3}$ and Chuang-Ye Hong ${ }^{1,4,5^{*}}$
}

\begin{abstract}
Magnolia officinalis has been widely used in traditional Chinese medicine. Magnolol, an active component isolated from Magnolia officinalis, is known to be a cardiovascular protector since 1994. The multiplex mechanisms of magnolol on cardiovascular protection depends on cell types and dosages, and will be reviewed and discussed in this article. Magnolol under low and moderate dosage possesses the ability to protect heart from ischemic/ reperfusion injury, reduces atherosclerotic change, protects endothelial cell against apoptosis and inhibits neutrophil-endothelial adhesion. The moderate to high concentration of magnolol mainly acts on smooth muscle cells and platelets. Magnolol induces apoptosis in vascular smooth muscle cells at moderate concentration and inhibits proliferation at moderate and high concentration. High concentration of magnolol also abrogates platelet activation, aggregation and thrombus formation. Magnolol also serves as an smooth muscle relaxant only upon the high concentration. Oral intake of magnolol to reach the therapeutic level for cardiovascular protection is applicable, thus makes magnolol an agent of great potential for preventing cardiovascular diseases in high-risk patients.
\end{abstract}

Keywords: Magnolol, Cardiomyocytes, Vascular endothelial cells, Smooth muscle cells, Inflammation, Antioxidant

\section{Review}

Magnolol is an active component isolated from Magnolia officinalis (Magnolia bark). Magnolia officinalis is a traditional Chinese medicine widely used in facilitating bowel movement and ameliorate abdominal fullness. The bark is stripped from the stems, branches, and roots of Magnolia tree, and which is highly aromatic and polyphenolic components containing magnolol and honokiol (Figure 1) [1,2]. In addition to purification of magnolol from Magnolia-bark, preparation of synthetic magnolol/ honokiol, its analogues and derivatives has been well established [3-6]. In the past decades, magnolol has been characterized as an anti-oxidant, anti-depressant, antiallergic, anti-cancer and anti-microbial agent [7-11].

Using isolated rat heart mitochondria as an ex vivo model, Hong et al. demonstrated that magnolol exhibited free radical scavenging activities shown by the diphenyl-ppicrylhydrazyl assay, which was less potent than alpha-

\footnotetext{
* Correspondence: hongprof@tmu.edu.tw

'Graduate Institute of Clinical Medicine, Taipei Medical University, Taipei, Taiwan

${ }^{4}$ Department of Medicine, Wan Fang Hospital, Taipei Medical University, Taipei, Taiwan

Full list of author information is available at the end of the article
}

tocopherol (vitamin E) [12]. However, the ability of inhibiting ADP- or ferrous sulfate-induced heart mitochondrial lipid peroxidation from magnolol was 1000 times higher than which from alpha-tocopherol [12]. The lipid peroxidation inhibition ability by magnolol was not only found in isolated heart mitochondria, but also shown in preventing or treating rat from cecal ligation-induced sepsis by a dose-dependent manner from $10^{-6}$ to $10^{-2} \mathrm{mg} / \mathrm{kg}$ of magnolol via intravenous injection [13].

The potent antioxidant activities of magnolol and honokiol are thought to be the contribution of hydroxyl and allylic groups on a biphenolic moiety. The hydroxyl group on biphenolic moiety results in magnolol/honokiol against reactive oxygen species, inhibiting cell proliferation and antimicrobial activity $[3,6,14]$. It has been reported that most of allylated biphenolic magnolol/honokiol analogues possessed anti-proliferative activity and anti-MRSA capacity while magnolol analogues with flexible allylated biphenolic structure showed a better anti-virus activity than simple allylated ones $[4,5]$. In addition, the derivatives of honokiol with the biaryl structure bearing a hydroxyl and a allyl groups at the 4'-hydroxyl shown to be essential for neurite outgrowth-promoting activity [15].

\section{Biomed Central}




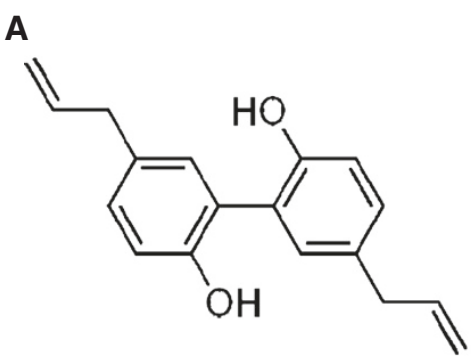

Magnolol
5,5"-Diallyl-biphenyl-2,2"-diol
MolecularFormula: $\mathrm{C}_{18} \mathrm{H}_{18} \mathrm{O}_{2}$
Molecular Weight: 226.334
Melting Point: $103^{\circ} \mathrm{C}$
Solubility: lipophilic
B

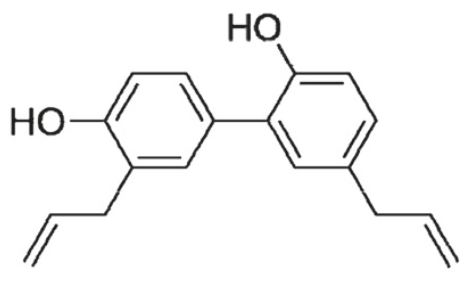

Honokiol

5,3'-Diallyl-biphenyl-2,4'-diol

Molecular Formula: $\mathrm{C}_{18} \mathrm{H}_{18} \mathrm{O}_{2}$

Molecular Weight: 226.334

Melting Point: $87.5^{\circ} \mathrm{C}$

Solubility: lipophilic

Figure 1 Structure and chemical characteristics of magnolol and honokiol. Magnolol (A) and honokiol (B) are isomers extracted from Magnolia officinalis. Both of magnolol and honokiol are lipophilic, biphenoid structure with molecular weight of 226.334 . The melting point of magnolol is higher than that of honokiol.

The multiplex functional regulation by magnolol is a cell type specific effect. In this article, we will focus on tissues/ cells involved in cardiovascular diseases, i.e. cardiomyocytes, endothelial cells, neutrophils, macrophages, platelets and smooth muscle cells in coronary artery and aorta. Literatures of magnolol research on cardiovascular protection, including our efforts, in the past 20 years will be reviewed and summarized in this article.

\section{Effects and molecular mechanisms of magnolol on cardiovascular system}

The cardiovascular protection potentiality of magnolol through its antioxidant activity is first demonstrated by Hong et al. in 1994 [12]. It is well known that free radicals attack lipid membrane, protein and DNA. Excessive free radicals induce lipid peroxidation, protein denature and DNA damage, and that triggers cell death. In addition, vascular stenosis, cell death and inflammation are the major progressive factors to worse the cardiac function as well as vascular complications during cardiovascular dysfunction. In the past 20 years, magnolol has been found to have diverse functions in different cells of cardiovascular system. Those effects are dose-related, and are the consequence of different molecular mechanisms regulated by magnolol.

\section{Magnolol protects heart from myocardial infarction and ischemia/reperfusion injury Magnolol reduces ventricular arrhythmia} In a series of animal studies, Hong and his team members demonstrated that intravenous injection of magnolol at the dosage above $10^{-6} \mathrm{mg} / \mathrm{kg}$ before coronary artery ligation successfully inhibited both ischemia- and reperfusioninduced ventricular tachycardia and ventricular fibrillation, while $10^{-5} \mathrm{mg} / \mathrm{kg}$ of magnolol and above significantly reduced the infarct size [16]. Honokiol had been found to more efficient for reducing ligation-induced infarct size $\left(>10^{-6} \mathrm{mg} / \mathrm{kg}\right.$ ) but less sensitive to ventricular arrhythmia inhibition (at the dosage of $10^{-4} \mathrm{mg} / \mathrm{kg}$ ) than magnolol [17]. Furthermore, to explore the mechanism of ventricular arrhythmia inhibition by magnolol, pretreatment of nitric oxide inhibitor (L-NAME) or cyclooxygenase inhibitor (aspirin) before ligation demonstrated that nitric oxide synthesis may also be involved in the anti-arrhythmic effect of magnolol or honokiol $\left(10^{-7} \mathrm{mg} / \mathrm{kg}\right)[18]$.

\section{Magnolol inhibits neutrophil infiltration in myocardium and restores systolic wall thickening fraction}

Magnolol protected rabbit myocardium against coronary artery ligation-induced stunning evidenced by significantly enhancing the recovery of systolic wall thickening fraction 60 minutes after coronary artery reperfusion at the dosage from $10^{-4}$ to $10^{-3} \mathrm{mg} / \mathrm{kg}$, relatively higher than which of reducing ventricular arrhythmia [19]. Under such concentration $\left(2-5 \times 10^{-4} \mathrm{mg} / \mathrm{kg}\right)$, magnolol could also prevent rat myocardium from ischemia/ reperfusion injury and neutrophil infiltration [20].

\section{Magnolol promotes coronary vasodilatation and inhibits myocardium apoptosis}

Magnolol has been reported to possess the ability of reducing coronary arterial resistance after ligation under a high 
dosage $\left(10^{-1} \mathrm{mg} / \mathrm{kg}\right)$ by measuring the rabbit coronary vascular resistance using pulsed Doppler velocimetry [21], suggesting that the underlying mechanism of magnolol responsible for coronary vasodilatation and myocardium protection is independent. Except for coronary vasodilatation, high concentration of magnolol at $10 \mathrm{mg} / \mathrm{kg}$ via intraperitoneal injection also demonstrated the ability to prevent myocardial ischemia and reperfusion injury associated cardiomyocytes apoptosis through enhancing the activation of ERK1/2 and modulation of the Bcl-xl proteins [22]. However, the regulation of ERK1/2 signaling pathway by magnolol shows a reciprocal effect in cardiomyocyte and cardiofibroblast. For rat cardiac fibroblast, on the contrary, magnolol $(10 \mu \mathrm{M})$ significantly inhibited urotensin-IIinduced proliferation through inhibiting ERK1/2 activation and interfering with ROS generation [23]. The in vitro results from cardiac fibroblasts indicate that magnolol may have a potential to decrease cardiac fibrotic change during the regenerative stage after infarction.

\section{Magnolol prevents atherosclerosis and vessel restenosis Magnolol attenuates postangioplastic restenosis}

Hyperlipidemia, resulting in atherosclerotic change, is one of the major risk factors for myocardial infarction and postangioplastic restenosis. In 2001, using balloon injury in a hyperlipidemic rabbit, Chen et al. demonstrated that daily intramuscular injection of $10^{-3} \mathrm{mg} / \mathrm{kg}$ magnolol for 6 weeks attenuated intimal thickening and MCP-1 expression induced by balloon denudation. Such effect of magnolol was related to inhibition of LDL oxidation rather than decreasing plasma lipid level [24], showing that lipid peroxidation inhibition by magnolol plays a role to prevent vessel restenosis.

\section{Magnolol induces apoptosis and inhibits proliferation in vascular smooth muscle cells}

Although ox-LDL contributes to vessel stenosis, intimal thickening is a direct consequence of vascular smooth cells proliferation. In experimental studies, magnolol was found to inhibit intimal hyperplasia induced by highcholesterol diet [24]. Next, several research groups work on investigating the direct effect of magnolol on vascular smooth muscle cells instead of LDL peroxidation.

Magnolol (5 to $20 \mu \mathrm{M}$ ) per se dose-dependently induced apoptosis in vascular smooth muscle cells by increasing DNA fragmentation and activating caspase-3 and -9 activities. Magnolol reduced mitochondrial membrane potential which was Bcl-2 dependent [25]. However, under serum or TNF $\alpha$ stimulation, vascular smooth muscle cell proliferation can be abrogated by magnolol. Wu et al. reported that magnolol at the concentration of $50 \mu \mathrm{g} / \mathrm{ml}(200 \mu \mathrm{M})$ significantly reduced vascular smooth muscle cells progressing to the $\mathrm{S}$-phase when DNA synthesis was triggered by serum. The proliferation inhibition by magnolol was also associated with reducing malondialdehyde formation, downregulation of NF- $\mathrm{kB}$ and increasing caspase-3 [26], suggesting that the proliferation inhibition may a net result from G1 cell cycle arrest, anti-oxidation and apoptosis induction by magnolol. Indeed, in the following research by Kim's group, 5 to $20 \mu \mathrm{M}$ of magnolol concentrationdependently inhibited TNF $\alpha$-induced vascular smooth cell proliferation through reducing ERK1/2 activity. Inhibition of ERK1/2 activity led to G1 cell cycle arrest which was a consequence of p21 upregulation and subsequent decrease in CDK-2 and CDK-4. Hence, magnolol also decreased MMP-9 promoter activity in vascular smooth muscle cells in response to TNF $\alpha$, and which was transcriptional regulated by NF-kB and AP-1 [27].

\section{Magnolol promotes vessel dilation}

In addition to affect on smooth muscle cell numbers, magnolol also works as a smooth muscle relaxant. In 1975, magnolol was found to act as a centrally acting muscle relaxant [28], such an effect was referred to magnolol with two hydroxyls into 2- and 2'-position of diphenyl molecule [29]. In 1990, Teng et al. found that high concentration as $10-100 \mu \mathrm{g} / \mathrm{ml}(40-400 \mu \mathrm{M})$ of magnolol efficiently blocked norepinephrine- or high $\mathrm{K}$ ${ }^{+}$-induced contraction of rat aorta in the present of endothelium [30]. Since that time, endothelium-derived relaxing factor and voltage-gated $\mathrm{Ca}^{2+}$ channels are thought to be the targets of magnolol in releasing smooth muscle tone. Further studies reported that both magnolol and honokiol at the concentration from 0.1 to $100 \mu \mathrm{M}$ irreversibly abrogated carbachol- and high $\mathrm{K}$ ${ }^{+}$-induced smooth muscle contractions in porcine trachea and rat uterine without affecting the basal muscle tension. The mechanism of smooth muscle tone inhibition by magnolol directed to the blockade of $\mathrm{Ca}^{2+}$ influx through voltage-operated $\mathrm{Ca}^{2+}$ channels instead of $\mathrm{Ca}^{2+}$ release from intracellular $\mathrm{Ca}^{2+}$ stores $[31,32]$.

\section{Magnolol inhibits vascular endothelial cell death}

Magnolol shows reciprocal regulation on ERK1/2 activity in cardiomyocyte and fibroblast. Alternatively, magnolol inhibits the activation of NF- $\mathrm{kB}$ signaling pathway resulting in different effects on vascular smooth muscle cells, endothelial cells and neutrophils.

For vascular smooth muscle cells, magnolol induces cell death via activation of intrinsic (mitochondrial) apoptosis; however, for vascular endothelial cells, magnolol protects the cell viability through inhibition of intrinsic apoptosis. Using copper-induced ox-LDL to trigger intrinsic apoptosis, magnolol $(2.5$ to $20 \mu \mathrm{M})$ showed the protective effect on vascular endothelial cells via removal of intracellular ROS, so that ROS-induced cytochrome $c$ releasing, caspase- 3 activation as well as 


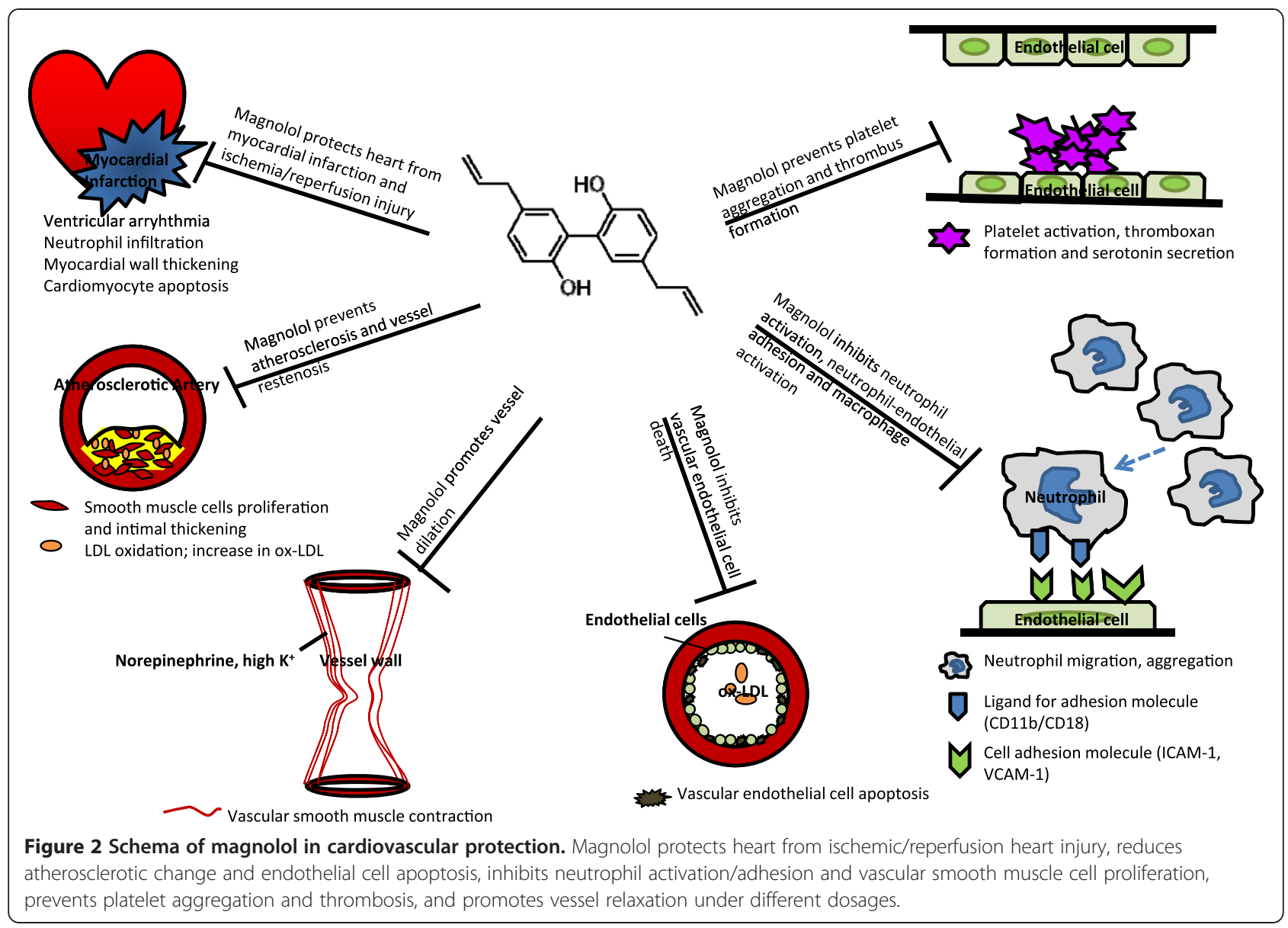

NF- $\mathrm{kB}$ activation was inhibited [33]. Honokiol, similar to magnolol, protect vascular endothelial cells against apoptosis. In an in vitro model of hyperglycemiainduced endothelial damage, honokiol $(0.125$ to $1 \mu \mathrm{M})$ suppressed NF- $\mathrm{kB}$ regulated COX-2 upregulation and intrinsic apoptosis [34]. Although it has been demonstrated that magnolol protects endothelial cells from the ox-LDL-induced apoptosis, the endothelial protection with magnolol per se is still unclear so far.

\section{Magnolol inhibits acute inflammation}

Magnolol inhibits macrophage activation and suppresses neutrophil aggregation, activation and migration

In LPS-activated macrophage, both magnolol and honkiol inhibited iNOS expression and TNF $\alpha$ releasing. However, honokiol (IC50 6.4 $\mu \mathrm{M}$ ) showed stronger inhibition effect on macrophage than magnolol (IC50 $16.8 \mu \mathrm{M}$ ) [35].

During acute cardiovascular injury, neutrophil aggregation, activation, migration, endothelial adhesion and infiltration initiate a series of inflammatory responses which worse the cardiovascular function. Magnolol $(30-90 \mu \mathrm{M})$ per se induced cytosolic-free $\mathrm{Ca}^{2+}$ elevation in neutrophil by stimulating $\mathrm{Ca}^{2+}$ release from internal stores and $\mathrm{Ca}^{2+}$ influx across the plasma membrane via activating inositol trisphosphate signalling pathway [36]. Upon PMA stimulation, magnolol at low concentration $(0.1-10 \mu \mathrm{M})$ dosedependently diminished PMA-induced Mac-1 (CD11b/ CD18) upregulation in neutrophil and reduced sequential adhesion ability. Such effect was similar to exogenous superoxide dismutase or catalase showing that magnolol served as an anti-oxidant in abrogating neutrophil adhesion [37]. Furthermore, in vivo study demonstrated that magnolol suppressed cytosolic PKC activity in [3 H]phorbol 12,13-dibutyrate-labeled neutrophil rather than rat brain PKC activity with an IC 50 of $24.2 \pm 1.7 \mu \mathrm{M}$. The attenuation of PKC activity in neutrophil by magnolol was responsible for its inhibition of neutrophil aggregation [38]. Hence, magnolol at 5-50 $\mu \mathrm{M}$ showed significantly suppress $\mathrm{fMLP}$-activated human neutrophil migration in a concentration-dependent manner [20]. The above findings support that magnolol directly regulates neutrophil in an inflammatory environment.

\section{Magnolol reduces neutrophil-endothelial adhesion}

The next issue should be answered is whether magnolol can block the neutrophil-endothelial adhesion. For vascular endothelial cells, suppression of NF- $\mathrm{kB}$ regulated signals by magnolol leaded to anti-apoptotic effect $[33,34]$. It 
Table 1 Summary of in vivo magnolol effect on cardiovascular system

\begin{tabular}{|c|c|c|}
\hline Dosage & Effect & Reference \\
\hline \multicolumn{3}{|l|}{ Low $\left(10^{-7} \sim 10^{-4} \mathrm{mg} / \mathrm{kg}\right)$} \\
\hline $10^{-7 \sim-6} \mathrm{mg} / \mathrm{kg}$ (i.v.) & Prevent post Ml-induced ventricular arrythmia & {$[16,18]$} \\
\hline $10^{-5} \mathrm{mg} / \mathrm{kg}$ (i.v.) & Decrease Ml-induced infarct size & [16] \\
\hline \multicolumn{3}{|c|}{ Moderate $\left(10^{-4 \sim} 10^{-2} \mathrm{mg} / \mathrm{kg}\right)$} \\
\hline $10^{-4 \sim-3} \mathrm{mg} / \mathrm{kg}$ (i.v.) & Protect myocardium against Ml-induced myocardial wall thinning & [19] \\
\hline $2-5 \times 10^{-4} \mathrm{mg} / \mathrm{kg}$ (i.v.) & Decrease neutrophil infiltration in infarct heart & [20] \\
\hline $10^{-3} \mathrm{mg} / \mathrm{kg}$ (i.m.) daily & Attenuate balloon-induced intimal thickening and inhibit LDL oxidation & [24] \\
\hline $10^{-3} \mathrm{mg} / \mathrm{kg}$ (i.m.) daily & Attenuate hypercholesteremia-induced intimal thickening, TNFa and VCAM-1 elevation in an aorta. & [40] \\
\hline \multicolumn{3}{|l|}{ High $\left(\geqq 10^{-1} \mathrm{mg} / \mathrm{kg}\right)$} \\
\hline $10^{-1} \mathrm{mg} / \mathrm{kg}$ (i.v.) & Reduce coronary artery resistance after $\mathrm{Ml}$ & [21] \\
\hline 10 mg/kg (i.p.) & Prevent Ml-induced cardiomyocyte apoptosis & [22] \\
\hline
\end{tabular}

i.v.: intravenous injection; i.m.: intramuscular injection; i.p.: intraperitoneal injection.

is also known that activation of NF- $\mathrm{KB}$ signaling pathway in vascular endothelial cells also results in both proinflammatory cytokines/chemokines releasing and cell adhesion molecules expression such as VACM-1, ICAM1 and endothelial cell selectin [39], that promotes neutrophil-endothelial adhesion. In 2002, Chen et al. demonstrated that magnolol (5 and $10 \mu \mathrm{M}$ ) selectively inhibited TNFo-induced VACM-1 expression by abrogating nuclear translocation of NF-kB p65 in human aortic endothelial cells. They further confirmed that in vivo magnolol $\left(10^{-3} \mathrm{mg} / \mathrm{kg}\right.$ daily via intramuscular injection) attenuated the intimal thickening, TNF $\alpha$ and VCAM-1 protein expression in the thoracic aortas of cholesterol-fed rabbits [40]. Besides, magnolol at the concentration above $20 \mu \mathrm{M}$ completely abolished IL-6-induced STAT3 phosphorylation in bovine aortic endothelial cells, and further downregulated ICAM-1, cyclin D1 and MCP-1 expression. The downregulation of ICAM-1 by magnolol resulted in suppression of IL-6-induced monocytic cells adhesion to endothelial cells [41].

\section{Magnolol prevents platelet aggregation and thrombus formation}

The anti-platelet effect of magnolol and honokiol has been known for more than 20 years. Teng et al. firstly reported that magnolol and honokiol inhibited

Table 2 Summary of in vitro magnolol effect on cardiovascular system

\begin{tabular}{|c|c|c|}
\hline Concentration & Effect & Reference \\
\hline \multicolumn{3}{|c|}{ Low $(\leqq 1 \mu \mathrm{M})$ to Moderate } \\
\hline $0.1-10 \mu \mathrm{M}$ & Diminish PMA-induced neutrophil activation and reduce neutrophil adhesion ability & {$[44]$} \\
\hline \multicolumn{3}{|c|}{ Moderate $(1-100 \mu \mathrm{M})$} \\
\hline $5-10 \mu \mathrm{M}$ & Inhibited TNFa-induced VACM-1 expression in aortic endothelial cells & {$[37]$} \\
\hline $10 \mu \mathrm{M}$ & Inhibit proliferation of cardiac fibroblasts & {$[23]$} \\
\hline $16.8 \mu \mathrm{M}$ & Inhibit LPS-induced macrophage activation & {$[35]$} \\
\hline $5-20 \mu \mathrm{M}$ & Induce intrinsic apoptosis in vascular smooth muscle cells & {$[25]$} \\
\hline $5-20 \mu \mathrm{M}$ & Inhibit TNFa-induced vascular smooth muscle cell proliferation & {$[27]$} \\
\hline$>20 \mu \mathrm{M}$ & Downregulate IL-6-induced ICAM-1 expression in endothelial cells and suppress monocyte adhesion to endothelial cells & [41] \\
\hline $2.5-20 \mu \mathrm{M}$ & Inhibit copper-induced ox-LDL triggered endothelial cell apoptosis & {$[33,34]$} \\
\hline $24.2 \mu \mathrm{M}$ & Inhibit neutrophil aggregation & {$[38]$} \\
\hline $3-30 \mu \mathrm{M}$ & Inhibit collagen-induced platelet serotonin release & {$[43]$} \\
\hline $5-50 \mu \mathrm{M}$ & Suppress fMLP-activated neutrophil migration & {$[20]$} \\
\hline $30-90 \mu \mathrm{M}$ & induce cytosolic-free Ca2+ elevation in neutrophil & {$[36]$} \\
\hline \multicolumn{3}{|c|}{ Moderate to High ( $\geqq 100 \mu \mathrm{M})$} \\
\hline $200 \mu \mathrm{M}$ & Reduce serum-induced vascular smooth muscle cell proliferation & {$[26]$} \\
\hline $40-400 \mu \mathrm{M}$ & block norepinephrine- or high $\mathrm{K}^{+-}$induced contraction of aorta & {$[30]$} \\
\hline $60-150 \mu \mathrm{M}$ & Inhibit biosynthesis of platelet-activating factor from PMNs & {$[44]$} \\
\hline
\end{tabular}


thromboxan B2 formation as well as intracellular calcium mobilization in platelets caused by collagen, arachidonic acid or thrombin [42]. Besides, collageninduced platelet serotonin release was also inhibited by magnolol $(3-30 \mu \mathrm{M})$ [43]. Using TCA method to measure the radioactive product and albumin in rat spleen microsomes or membrane fractions of human PMNs, magnolol and honokiol significantly inhibited the activity of acetyl-CoA: 1-alkyl-sn-glycero-3-phosphocholine acetyltransferase, a key enzyme in the biosynthesis of platelet-activating factor (IC50 60-150 $\mu \mathrm{M}$ ) [44].

\section{Pharmacodynamics, Pharmacokinetics and Safety Test of Magnolol}

The pharmacokinetics of magnolol are linear in vivo because that there were no significant difference in elimination half-life and total body clearance between intravenous injection and intravenous infusion [45]. The linear pharmacokinetics was found from a dose of 2 to $10 \mathrm{mg} / \mathrm{kg}$ via intravenous injection [46]. After rectal administration of magnolol $(24.4 \mathrm{mg} / \mathrm{kg})$ and honokiol $(13.5 \mathrm{mg} / \mathrm{kg})$, respectively, the linear concentration-time profiles of magnolol (from 40 to $400 \mathrm{ng} / \mathrm{ml}$ ) and honokiol (from 20 to $200 \mathrm{ng} / \mathrm{ml}$ ) in rat plasma could also be detected using a HPLC method [47]. However, LC/MS offered a larger range of linear concentration-time profiles of both magnolol and honokiol from 3.13 to $800 \mathrm{ng} / \mathrm{ml}$ [48].

In experimental studies, intravenous injection of magnolol at the dosage of $2-10 \mathrm{mg} / \mathrm{kg}$ revealed the Cmax around $10 \mu \mathrm{g} / \mathrm{ml}(40 \mu \mathrm{M})$, while the Cmax of $20 \mathrm{mg} / \mathrm{kg}$ magnolol via oral administration was $0.1 \mu \mathrm{g} / \mathrm{ml}$ $(0.4 \mu \mathrm{M})$. The oral bioavailability of magnolol was around 4-5\% [49,50]. The elimination half-life of magnolol was around 15 minutes and total body clearance was $72-75 \mathrm{ml} / \mathrm{min} / \mathrm{kg}$ [50,51]. Tissue distribution of magnolol was predominantly in the liver, kidney, brain, lung, and heart after oral administration [50]. In healthy human subject, oral administration of magnolol could retain in plasma for more than 1 hour [51].

The safety test of magnolol or extracts of Magnolia bark has been reported. In pre-clinical study, oral administration (mice: $0.625-2.5 \mathrm{~g} / \mathrm{kg}$; rat: $0.06-0.48 \mathrm{~g} / \mathrm{kg} /$ day for 21 days or $0.06-0.24 \mathrm{~g} / \mathrm{kg} /$ day for 90 days) of ethanol extracts ( $94 \%$ magnolol and $1.5 \%$ honokiol) of Magnolia bark neither induced drug-related side effects nor altered immune response [52,53]. However, oral administration of 5-10 g/kg of Magnolia bark extracts for 14 days decreased liver and renal function in rat [54]. Daily oral intake $7.5 \mathrm{~g}$ of Hangekobokuto (containing $3 \mathrm{~g}$ Magnolia cortex per $17 \mathrm{~g}$ of Hangekobokuto) before meal for 2 weeks did not change the gastrointestinal symptom rating scale for healthy group and improved gastrointestinal symptoms in patients with functional dyspepsia [55]. A randomized, double-blind, placebocontrolled clinical study showed that oral administration of capsuled extracts of Magnolia officinalis and Phellodendron amurense $(250 \mathrm{mg}$, three times a day for 6 weeks) was well tolerated in both healthy and obese patients, and regulation of cortisol only in obese patients was a benefit for weight control [56].

\section{Summary}

Neutrophil infiltration, change of microRNA regulation, and activation of innate immunity and subsequent proinflammatory cytokine releasing as well as increasing oxidative stress in response to myocardial ischemic/ reperfusion injury lead to cardiac arrhythmia and myocardial contractile dysfunction [57-59]. Endothelial damage triggers inflammation reaction and atherosclerotic change, platelet aggregation and thrombus formation, while mediators released by inflammatory cells promote vascular smooth muscle cell proliferation, all of which result in vascular occlusion [60-62]. The cardiovascular protections of magnolol result from attenuating ische$\mathrm{mic} /$ reperfusion heart injury, reducing atherosclerotic change and endothelial cell apoptosis, inhibiting neutrophil activation/adhesion and vascular smooth muscle cell proliferation, preventing platelet aggregation and thrombosis, and promoting vessel relaxation (Figure 2), and such cardiovascular protection effects regulated by magnolol are cell type specific and dose-related. In this article, we define that magnolol concentration at $10^{-7}$ $10^{-4} \mathrm{mg} / \mathrm{kg}$ in vivo or $\leqq 1 \mu \mathrm{M}$ in vitro acts as a low dosage, $10^{-4}-10^{-2} \mathrm{mg} / \mathrm{kg}$ in vivo or $1-100 \mu \mathrm{M}$ in vitro is the moderate dosage, while $\geqq 10^{-1} \mathrm{mg} / \mathrm{kg}$ in vivo or $\geqq 100 \mu \mathrm{M}$ in vitro will be the high dosage (Tab 1 and 2 ).

In general, lipid peroxidation inhibition ability of magnolol is linear, dose-dependent in physiologically low and moderate dosages. Under low dosage, anti-oxidation capacity of magnolol results in preventing myocardial infarction-induced ventricular arrhythmia and reducing infarct area. Under moderate dosage, the lipid peroxidation inhibition by magnolol protects myocardium from ischemic/reperfusion injury and neutrophil infiltration, attenuates postangioplastic restenosis and atherosclerotic change. Moderate concentration of magnolol also reduces vascular endothelial cell apoptosis via inhibiting NF- $\kappa$ B signaling pathway. Besides, the anti-inflammation ability of magnolol is promising under moderate concentration resulting in abrogating neutrophil Mac-1 mediated adhesion ligand expression, PKC-associated migration, macrophage activation and neutrophilendothelial adhesion by reduction of VACM-1 and ICAM-1 expression via inhibiting NF- $\mathrm{KB}$ and STAT3 signaling pathway, respectively.

Moderate to high concentration of magnolol acts on vascular smooth muscle cells. Moderate concentration 
of magnolol triggers intrinsic apoptosis while moderate and high dosage further inhibit vascular smooth muscle cell proliferation through decreasing ERK1/2 activity. In addition, inhibition of platelet activation, aggregation as well as thrombus formation by magnolol are observed under the moderate to high concentration. It is worth to notify that only a high dosage of magnolol can release smooth muscle tone and subsequently lead to vasodilatation via regulation of $\mathrm{Ca}^{2+}$ channel. All the cell type specific and dose-related effects of magnolol on cardiovascular protection have been summarized in Tables 1 and 2 .

\section{Conclusion}

Multifunction of magnolol on cardiovascular system suggests the great potential of such a traditional Chinese medicine in treating or preventing cardiovascular diseases. From the clinical point of view, all the cardiovascular protection in vivo by magnolol can be observed under or below the dosage of $0.1 \mathrm{mg} / \mathrm{kg}$ via intravenous injection according to those above research achievements. To reach the therapeutic level through oral administration with $5 \%$ of oral bioavailability, $2 \mathrm{mg} / \mathrm{kg}$ per day, i.e. daily $120 \mathrm{mg}$ of magnolol for a $60-\mathrm{kg}$ adult, may be sufficient for cardiovascular protection, and such a dosage is applicable. We conclude that magnolol is a non-steroid and non-aspirin compound with strong cardiovascular protection ability, which has a great potential of preventing cardiovascular insults under daily intake in high-risk patients. Further clinical trials for investigation of safety and therapeutic range of magnolol in a healthy and a high-risk group should be warranted.

\section{Abbreviations}

MRSA: Methicillin Resistant Staphylococcus Aureus; GABA: $\gamma$-aminobutyric acid; LTB4: Leukotriene B4; LTC4: Leukotriene C4; IgE: Immunoglobulin E; S. aureus: Staphylococcus aureus; DNA: Deoxyribonucleic acid; ADP: Adenosinediphosphate; L-NAME: L-N G-nitro-arginine methyl ester; ERK1/2: Extracellullar signal-regulated kinase 1/2; BCl-xl: B-cell lymphomaextra large; ROS: Reactive oxygen species; MCP-1: Monocyte chemotactic protein-1; LDL: Low density lipoprotein; Ox-LDL: Oxidized low density lipoprotein; Bcl-2: B-cell lymphoma 2; TNFa: Tumor necrosis factor-alpha; NF-KB: Nuclear factor kappa-light-chain-enhancer of activated B cells; CDK: Cyclin-dependent kinase; MMP-9: Matrix metalloproteinase-9; AP-1: Activation protein-1; K: Potassium; Ca: Calcium; COX-2: Cyclooxygenase2: PMA: Phorbol-12-myristate-13-acetate; PKC: Protein kinase C; f-MLP: $\mathrm{N}$-formylmethionyl-leucyl-phenylalanine; VACM-1: Vascular cell adhesion molecule-1; ICAM-1: Intercellular cell adhesion molecule-1; IL-6: interleukin-6; LPS: Lipopolysaccharide; iNOS: Inducible nitric oxide synthetase; STAT3: Signal transducer and activator of transcription protein 3; TCA: Trichloroacetic acid; PMNs: Polymorphonuclear leukocytes; HPLC: High-performance liquid chromatographic; LC/MS: Liquid chromatography tandem mass spectrometry; Cmax: Maximal plasma concentration.

\section{Competing interests}

The authors declare that they have no competing interests.

\section{Authors' contributions}

$\mathrm{JH}$ carried out the design, acquisition, analysis and interpretation of data, drafting the manuscript. CY had contributed to conception, design and critical version of important intellectual content and final approval of the manuscript. All authors read and approved the final manuscript.

\section{Authors' information}

Dr. Jennifer Hui-Chun Ho is the Director of Center for Stem Cell Research and the Deputy Director of Medical Research and Education at Wan Fang Hospital, Taipei Medical University, and is also an Associate Professor at Graduate Institute of Clinical Medicine, Taipei Medical University. The main research work in her lab is using small molecule or physical stimulus to modify stem cell activity and enhance the efficacy of stem cell transplantation.

Dr. Chuang-Ye Hong was the formal Superintendent of Wan Fang Hospital, Taipei Medical University and also the Professor at Graduate Institute of Clinical Medicine, Taipei Medical University and a consultant cardiologist at Wan Fang Hospital. Prof. Hong is an expert in pharmacological research of medical herbs on cardiovascular diseases. Prof. Hong was the Director of Institute of Traditional Medicine at National Yang-Ming University from 1992 to 1997, when he led a research team working on translational research of traditional Chinese medicine, especially magnolol and honokiol.

\section{Acknowledgements}

The authors acknowledge the financial supports of research grants from the National Science Council (NSC98-2314-B-038-010-MY3 and NSC99-2120-M -010-001-MY2, to JHH).

\section{Author details}

${ }^{1}$ Graduate Institute of Clinical Medicine, Taipei Medical University, Taipei, Taiwan. ${ }^{2}$ Center for Stem Cell Research, Wan Fang Hospital, Taipei Medical University, Taipei, Taiwan. ${ }^{3}$ Institute of Engineering in Medicine, University of California, San Diego, La Jolla, CA, USA. ${ }^{4}$ Department of Medicine, Wan Fang Hospital, Taipei Medical University, Taipei, Taiwan. ${ }^{5}$ Department of Medicine, Wan Fang Hospital, Taipei Medical University, 111Sec 3, Hsing-Long Rd, Taipei 116, Taiwan.

Received: 13 April 2012 Accepted: 26 June 2012

Published: 31 July 2012

\section{References}

1. Wu YT, Lin LC, Tsai TH: Simultaneous determination of honokiol and magnolol in Magnolia officinalis by liquid chromatography with tandem mass spectrometric detection. Biomed Chromatogr 2006, 20:1076-1081.

2. Liu L, Wu X, Fan L, Chen X, Hu Z: Separation and determination of honokiol and magnolol in herbal medicines by flow injection-capillary electrophoresis. Anal Bioanal Chem 2006, 384:1533-1539.

3. Fried $L E$, Arbiser JL: Honokiol, a multifunctional antiangiogenic and antitumor agent. Antioxid Redox Signal 2009, 11:1139-1148.

4. Amblard F, Govindarajan B, Lefkove B, Rapp KL, Detorio M, Arbiser JL, Schinazi RF: Synthesis, cytotoxicity, and antiviral activities of new neolignans related to honokiol and magnolol. Bioorg Med Chem Lett 2007, 17:4428-4431.

5. Srinivas J, Reddy Doma M, Singh PP, Kumar S, Malik F, Sharma A, Khan IA, Qazi GN, Kumar HM: Design and synthesis of novel magnolol derivatives as potential antimicrobial and antiproliferative compounds. Eur J Med Chem 2012, 51:35-41.

6. Wang Y, Li CY, Lin IH, Lee AR, Hu MK: Synthesis and radical scavenging of novel magnolol derivatives. J Pharm Pharmacol 2002, 54:1697-1703.

7. Ai J, Wang $X$, Nielsen M: Honokiol and magnolol selectively interact with GABAA receptor subtypes in vitro. Pharmacology 2001, 63:34-41.

8. Chen CR, Tan R, Qu WM, Wu Z, Wang Y, Urade Y, Huang ZL: Magnolol, a major bioactive constituent of the bark of Magnolia officinalis, exerts antiepileptic effects via the GABA/benzodiazepine receptor complex in mice. Br J Pharmacol 2011, 164:1534-1546.

9. Han SJ, Bae EA, Trinh HT, Yang JH, Youn UJ, Bae KH, Kim DH: Magnolol and honokiol: inhibitors against mouse passive cutaneous anaphylaxis reaction and scratching behaviors. Biol Pharm Bull 2007, 30:2201-2203.

10. Ho KY, Tsai CC, Chen CP, Huang JS, Lin CC: Antimicrobial activity of honokiol and magnolol isolated from Magnolia officinalis. Phytother Res 2001, 15:139-141.

11. Seo JU, Kim MH, Kim HM, Jeong HJ: Anticancer potential of magnolol for lung cancer treatment. Arch Pharm Res 2011, 34:625-633. 
12. Lo YC, Teng CM, Chen CF, Chen CC, Hong CY: Magnolol and honokiol isolated from Magnolia officinalis protect rat heart mitochondria against lipid peroxidation. Biochem Pharmacol 1994, 47:549-553.

13. Kong CW, Tsai K, Chin JH, Chan WL, Hong CY: Magnolol attenuates peroxidative damage and improves survival of rats with sepsis. Shock 2000, 13:24-28.

14. Clark AM, El-Feraly FS, Li WS: Antimicrobial activity of phenolic constituents of Magnolia grandiflora L. J Pharm Sci 1981, 70:951-952.

15. Esumi T, Makado G, Zhai H, Shimizu Y, Mitsumoto Y, Fukuyama Y: Efficient synthesis and structure-activity relationship of honokiol, a neurotrophic biphenyl-type neolignan. Bioorg Med Chem Lett 2004, 14:2621-2625.

16. Hong CY, Huang SS, Tsai SK: Magnolol reduces infarct size and suppresses ventricular arrhythmia in rats subjected to coronary ligation. Clin Exp Pharmacol Physiol 1996, 23:660-664.

17. Tsai SK, Huang SS, Hong CY: Myocardial protective effect of honokiol: an active component in Magnolia officinalis. Planta Med 1996, 62:503-506.

18. Tsai SK, Huang CH, Huang SS, Hung LM, Hong CY: Antiarrhythmic effect of magnolol and honokiol during acute phase of coronary occlusion in anesthetized rats: influence of L-NAME and aspirin. Pharmacology 1999, 59:227-233.

19. Huang CH, Hong CY, Tsai SK, Lai ST, Weng ZC, Chih CL, Hsieh YH: Intravenous pretreatment with magnolol protects myocardium against stunning. Planta Med 2000, 66:516-520.

20. Lee YM, Hsiao G, Chen HR, Chen YC, Sheu JR, Yen MH: Magnolol reduces myocardial ischemia/reperfusion injury via neutrophil inhibition in rats. Eur J Pharmacol 2001, 422:159-167.

21. Huang CH, Hong CY, Tsai SK, Lai ST: Effect of magnolol on coronary vascular resistance in rabbits: measurement with pulsed Doppler velocimetry. J Formos Med Assoc 2000, 99:554-558.

22. Jin YC, Kim KJ, Kim YM, Ha YM, Kim HJ, Yun UJ, Bae KH, Kim YS, Kang SS, Seo HG, Lee JH, Chang KC: Anti-apoptotic effect of magnolol in myocardial ischemia and reperfusion injury requires extracellular signalregulated kinase1/2 pathways in rat in vivo. Exp Biol Med (Maywood) 2008, 233:1280-1288

23. Liou JY, Chen YL, Loh SH, Chen PY, Hong CY, Chen JJ, Cheng TH, Liu JC: Magnolol depresses urotensin-II-induced cell proliferation in rat cardiac fibroblasts. Clin Exp Pharmacol Physiol 2009, 36:711-716.

24. Chen YL, Lin KF, Shiao MS, Chen YT, Hong CY, Lin SJ: Magnolol, a potent antioxidant from Magnolia officinalis, attenuates intimal thickening and MCP-1 expression after balloon injury of the aorta in cholesterol-fed rabbits. Basic Res Cardiol 2001, 96:353-363

25. Chen JH, Wu CC, Hsiao G, Yen MH: Magnolol induces apoptosis in vascular smooth muscle. Naunyn Schmiedebergs Arch Pharmacol 2003, 368:127-133.

26. Wu CH, Chen CW, Chen HC, Chang WC, Shu MJ, Hung JS: Elucidating the inhibitory mechanisms of magnolol on rat smooth muscle cell proliferation. J Pharmacol Sci 2005, 99:392-399.

27. Kim HM, Bae SJ, Kim DW, Kim BK, Lee SB, Lee US, Kim CH, Moon SK: Inhibitory role of magnolol on proliferative capacity and matrix metalloproteinase-9 expression in TNF-alpha-induced vascular smooth muscle cells. Int Immunopharmacol 2007, 7:1083-1091.

28. Watanabe K, Watanabe HY, Goto Y, Yamamoto N, Yoshizaki M: Studies on the active principles of magnolia bark. Centrally acting muscle relaxant activity of magnolol and hōnokiol. Jpn J Pharmacol 1975, 25:605-607.

29. Watanabe $H$, Watanabe $K$, Hagino K: Chemostructural requirement for centrally acting muscle relaxant effect of magnolol and honokiol, neolignane derivatives. J Pharmacobiodyn 1983, 6:184-190.

30. Teng CM, Yu SM, Chen CC, Huang YL, Huang TF: EDRF-release and $\mathrm{Ca}+(+)$-channel blockade by magnolol, an antiplatelet agent isolated from Chinese herb Magnolia officinalis, in rat thoracic aorta. Life Sci 1990, 47:1153-1161

31. $\mathrm{Ko} \mathrm{CH}$, Chen HH, Lin YR, Chan MH: Inhibition of smooth muscle contraction by magnolol and honokiol in porcine trachea. Planta Med 2003, 69:532-536.

32. Lu YC, Chen HH, Ko CH, Lin YR, Chan MH: The mechanism of honokiolinduced and magnolol-induced inhibition on muscle contraction and $\mathrm{Ca} 2+$ mobilization in rat uterus. Naunyn Schmiedebergs Arch Pharmacol 2003, 368:262-269.

33. Ou HC, Chou FP, Sheu WH, Hsu SL, Lee WJ: Protective effects of magnolol against oxidized LDL-induced apoptosis in endothelial cells. Arch Toxicol 2007, 81:421-432.
34. Sheu ML, Chiang CK, Tsai KS, Ho FM, Weng TI, Wu HY, Liu SH: Inhibition of NADPH oxidase-related oxidative stress-triggered signaling by honokiol suppresses high glucose-induced human endothelial cell apoptosis. Free Radic Biol Med 2008, 44:2043-2050.

35. Son HJ, Lee HJ, Yun-Choi HS, Ryu JH: Inhibitors of nitric oxide synthesis and TNF-alpha expression from Magnolia obovata in activated macrophages. Planta Med 2000, 66:469-471.

36. Wang JP, Chen CC: Magnolol induces cytosolic-free Ca2+ elevation in rat neutrophils primarily via inositol trisphosphate signalling pathway. Eur $J$ Pharmacol 1998, 352:329-334.

37. Shen YC, Sung YJ, Chen CF: Magnolol inhibits Mac-1 (CD11b/CD18)dependent neutrophil adhesion: relationship with its antioxidant effect. Eur J Pharmacol 1998, 343:79-86.

38. Wang JP, Lin PL, Hsu MF, Chen CC: Possible involvement of protein kinase $C$ inhibition in the reduction of phorbol ester-induced neutrophil aggregation by magnolol in the rat. J Pharm Pharmacol 1998, 50:1167-1172.

39. Chen YH, Lin SJ, Ku HH, Shiao MS, Lin FY, Chen JW, Chen YL: Salvianolic acid $B$ attenuates VCAM-1 and ICAM-1 expression in TNF-alpha-treated human aortic endothelial cells. J Cell Biochem 2001, 82:512-521.

40. Chen YH, Lin SJ, Chen JW, Ku HH, Chen YL: Magnolol attenuates VCAM-1 expression in vitro in TNF-alpha-treated human aortic endothelial cells and in vivo in the aorta of cholesterol-fed rabbits. Br J Pharmacol 2002, 135:37-47.

41. Chen SC, Chang YL, Wang DL, Cheng JJ: Herbal remedy magnolol suppresses IL-6-induced STAT3 activation and gene expression in endothelial cells. Br J Pharmacol 2006, 148:226-232.

42. Teng CM, Chen CC, Ko FN, Lee LG, Huang TF, Chen YP, Hsu HY: Two antiplatelet agents from Magnolia officinalis. Thromb Res 1988, 50:757-765.

43. Tsai TH, Tsai WJ, Chou CJ, Chen CF: Magnolol inhibits collagen-induced platelet serotonin release. Thromb Res 1995, 78:265-270.

44. Yamazaki R, Sugatani J, Fujii I, Kuroyanagi M, Umehara K, Ueno A, Suzuki Y, Miwa M: Development of a novel method for determination of acetylCoA:1-alkyl-sn-glycero-3-phosphocholine acetyltransferase activity and its application to screening for acetyltransferase inhibitors, Inhibition by magnolol and honokiol from Magnoliae cortex. Biochem Pharmacol 1994, 47:995-1006.

45. Tsai $\mathrm{TH}$, Chou CJ, Chen CF: Disposition of magnolol after intravenous bolus and infusion in rabbits. Drug Metab Dispos 1994, 22:518-521.

46. Tsai TH, Chou CJ, Chen CF: Pharmacokinetics and brain distribution of magnolol in the rat after intravenous bolus injection. J Pharm Pharmacol 1996, 48:57-59.

47. Wu X, Chen X, Hu Z: High-performance liquid chromatographic method for simultaneous determination of honokiol and magnolol in rat plasma. Talanta 2003, 59:115-121.

48. Yu Q, Xiang J, Tang W, Liang M, Qin Y, Nan F: Simultaneous determination of the 10 major components of Da-Cheng-Qi decoction in dog plasma by liquid chromatography tandem mass spectrometry. J Chromatogr $B$ Analyt Technol Biomed Life Sci 2009, 877:2025-2031.

49. Tsai TH, Chou CJ, Lee TF, Wang LCH, Chen CF: Pharmacokinetic and pharmacodynamic studies of magnolol after oral administration in rats. Pharmaceut Sci 1996, 2:191-193.

50. Lin SP, Tsai SY, Lee Chao PD, Chen YC, Hou YC: Pharmacokinetics, bioavailability, and tissue distribution of magnolol following single and repeated dosing of magnolol to rats. Planta Med 2011, 77:1800-1805.

51. Homma M, Oka K, Taniguchi C, Niitsuma T, Hayashi T: Systematic analysis of post-administrative saiboku-to urine by liquid chromatography to determine pharmacokinetics of traditional Chinese medicine. Biomed Chromatogr 1997, 11:125-131.

52. Li N, Song Y, Zhang W, Wang W, Chen J, Wong AW, Roberts A: Evaluation of the in vitro and in vivo genotoxicity of magnolia bark extract. Regul Toxicol Pharmacol 2007, 49:154-159.

53. Liu Z, Zhang X, Cui W, Zhang X, Li N, Chen J, Wong AW, Roberts A: Evaluation of short-term and subchronic toxicity of magnolia bark extract in rats. Regul Toxicol Pharmacol 2007, 49:160-171.

54. Yang HY, Chen CF: Pharmacology and toxicology of herbal medicine: subacute toxicity of commonly used Chinese drugs. J Toxicol Sci 1998, 23(Suppl 2):229-233.

55. Oikawa T, Ito G, Hoshino T, Koyama H, Hanawa T: Hangekobokuto (Banxiahoupo-tang), a Kampo Medicine that Treats Functional Dyspepsia. Evid Based Complement Alternat Med 2009, 6:375-378. 
56. Garrison R, Chambliss WG: Effect of a proprietary Magnolia and Phellodendron extract on weight management: a pilot, double-blind, placebo-controlled clinical trial. Altern Ther Health Med 2006, 12:50-54.

57. Ha T, Liu L, Kelley J, Kao R, Williams D, Li C: Toll-like receptors: new players in myocardial ischemia/reperfusion injury. Antioxid Redox Signal 2011, 15:1875-1893.

58. Kukreja RC, Yin C, Salloum FN: MicroRNAs: new players in cardiac injury and protection. Mol Pharmacol 2011, 80:558-564.

59. Machado NG, Alves MG, Carvalho RA, Oliveira PJ: Mitochondrial involvement in cardiac apoptosis during ischemia and reperfusion: can we close the box? Cardiovasc Toxicol 2009, 9:211-227.

60. Badimon L, Martínez-González J, Llorente-Cortés V, Rodríguez C, Padró T: Cell biology and lipoproteins in atherosclerosis. Curr Mol Med 2006, 6:439-456.

61. Orr AW, Hastings NE, Blackman BR, Wamhoff BR: Complex regulation and function of the inflammatory smooth muscle cell phenotype in atherosclerosis. J Vasc Res 2010, 47:168-180

62. Libby P, Ridker PM, Hansson GK: Leducq Transatlantic Network on Atherothrombosis: Inflammation in atherosclerosis: from pathophysiology to practice. J Am Coll Cardiol 2009, 54:2129-2138.

doi:10.1186/1423-0127-19-70

Cite this article as: $\mathrm{Ho}$ and Hong: Cardiovascular protection of magnolol: cell-type specificity and dose-related effects. Journal of Biomedical Science 2012 19:70.

\section{Submit your next manuscript to BioMed Central and take full advantage of:}

- Convenient online submission

- Thorough peer review

- No space constraints or color figure charges

- Immediate publication on acceptance

- Inclusion in PubMed, CAS, Scopus and Google Scholar

- Research which is freely available for redistribution 